\title{
Rebeliões de classe média? Precariedade e movimentos sociais em Portugal e no Brasil (2011-2013)
}

Middle Class Rebellions? Precarious Employment and Social Movements in Portugal and Brazil (2011-2013)

Rébellion de la classe moyenne? Précarité et mouvements sociaux au Portugal et au Brésil (2011-2013)

\section{Elísio Estanque}

\section{OpenEdition}

Journals

Edição electrónica

URL: http://journals.openedition.org/rccs/5540

DOI: $10.4000 /$ rccs. 5540

ISSN: 2182-7435

\section{Editora}

Centro de Estudos Sociais da Universidade de Coimbra

Edição impressa

Data de publição: 1 maio 2014

Paginação: 53-80

ISSN: 0254-1106

Refêrencia eletrónica

Elísio Estanque, «Rebeliões de classe média? Precariedade e movimentos sociais em Portugal e no Brasil (2011-2013) », Revista Crítica de Ciências Sociais [Online], 103 | 2014, posto online no dia 26 maio 2014, consultado o 21 dezembro 2020. URL : http://journals.openedition.org/rccs/5540 ; DOI : https:// doi.org/ $10.4000 /$ rccs. 5540

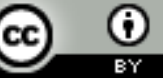




\section{ELÍSIO ESTANQUE}

\section{Rebeliões de classe média? \\ Precariedade e movimentos sociais em Portugal e no Brasil (2011-2013)}

O presente texto centra-se nas manifestações e nos movimentos de protesto que ocorreram ao longo dos últimos três anos, com especial atenção aos casos de Portugal e do Brasil. O argumento principal assenta na hipótese de que se trata de dinâmicas e tensões sociais onde transparece uma pulsão de classe média e na qual a juventude e a precariedade ocupam um papel decisivo. Apresenta-se um conjunto de dados e elementos empíricos sobre as desigualdades em Portugal, a fim de mostrar a natureza dos principais movimentos enquanto forças de indignação mobilizadas contra a supressão de direitos e a degradação das condições laborais. O caso brasileiro é analisado à luz da recomposição das condições das classes populares, mas tendo em conta os bloqueios e indefinições do modelo de desenvolvimento brasileiro. Analisa-se ainda a composição social dos manifestantes a partir de sondagens de rua realizadas à data dos acontecimentos.

Palavras-chave: classe média; contestação social; desigualdade social; movimentos sociais; precariedade laboral.

\section{Introdução}

$\mathrm{O}$ presente texto centra-se nas recentes manifestações e movimentos de protesto, com especial atenção aos casos de Portugal e do Brasil, partindo da hipótese de que se trata de dinâmicas e tensões sociais onde transparece uma pulsão de classe média e na qual a juventude e a precariedade ocupam um papel decisivo. A perspetiva adotada pretende ir além das teorias clássicas sobre os movimentos sociais do mundo ocidental, procurando situar o fenómeno no contexto socioeconómico mais geral - e de crise - a fim de discutir, por um lado, as implicações da fragmentação do trabalho assalariado e do aumento da precariedade na intensificação das desigualdades, e, por outro, a ineficácia das instituições e das políticas públicas, como fatores fundamentais da conflitualidade social que esteve na base das rebeliões sociais dos últimos anos. 
Começo por esclarecer que não se trata de uma "pesquisa" sociológica de raiz, mas antes de um registo ensaístico no qual procuro fazer uso de um conjunto de dados e elementos empíricos (alguns deles recolhidos através de fontes indiretas e outros de observação direta), com vista a explorar uma hipótese explicativa que sai fora dos cânones habituais do mundo académico. Assumo, portanto, o caráter controverso do artigo e admito até que esse poderá ser a sua maior virtude, desde que contribua para que as ciências sociais saiam do seu "gueto" e comecem a dirigir-se a um público mais amplo. É com esse espírito que procuro contribuir para uma desconstrução do conceito de "classe média", na sua tradicional conotação com passividade, individualismo e adesão acrítica à "ordem burguesa", realçando em especial as segmentações atualmente em curso no seio da classe trabalhadora, com a emergência de novos setores precários, instáveis e qualificados da força de trabalho. A isso junta-se também uma preocupação com a necessidade de atualização conceptual e analítica das formas mais recentes de ação coletiva, de que é exemplo o último ciclo de movimentos sociais onde se inserem os casos que se discutem neste artigo.

O objetivo do ensaio é, pois, identificar algumas características de novidade destas manifestações e mostrar até que ponto elas transportam uma dinâmica transformadora. Procura-se, em suma, responder a uma dupla pergunta: (1) quais os grupos sociais que mais têm alimentado esses movimentos, ou seja, quem se mobiliza?; e (2) qual o sentido da mudança que imprimiram na sociedade mais geral, quer nos momentos de maior intensidade, quer nas suas repercussões subsequentes?

A resistência a um statu quo, a uma ordem económica e política que defraudou expectativas, que ameaçou ou subtraiu direitos e bloqueou oportunidades parece obedecer a preocupações comuns em ambos os lados do Atlântico. Ao tentar revelar conexões com o mundo do trabalho e com o processo de empobrecimento de amplas camadas sociais - no caso de Portugal, estimulado pelas medidas de austeridade de categorias profissionais que haviam almejado um estatuto próximo dos estilos de vida da classe média urbana (assalariada) -, realça-se o potencial transformador das situações de rebelião, argumentando que os segmentos mobilizados nessas manifestações mantêm algum tipo de vínculo com padrões de consumo das camadas intermédias, apesar de isso ocorrer mais na dimensão subjetiva do que na condição socioeconómica, a qual parece ser, em ambos o casos, marcada pela instabilidade e precariedade. Assume-se que as camadas que integraram os protestos se debatem com processos de rápida redefinição de status e de padrões de consumo associados aos direitos laborais (ameaçados ou por consolidar) e a um profundo sentimento de frustração e de injustiça. 
A relação com o mercado de trabalho e suas metamorfoses, os impactos da economia global e da mercadorização crescente da vida social, as mutações tecnológicas e suas implicações nas atuais redes comunicacionais serão alguns dos fatores a considerar na identificação de similitudes e diferenças entre os dois contextos em estudo.

\section{Um ciclo de contestações globais - Revolução e ação}

Algumas das já antigas abordagens sobre os novos movimentos sociais (NMSs) das décadas de 1960-1970 vêm naturalmente perdendo acuidade. A definição clássica de Alain Touraine (1985 e 2006), e os seus conhecidos princípios definidores de movimento social - a identidade (quem somos?), a oposição (contra quem lutamos?) e a totalidade (por que sociedade lutamos?) - dificilmente poderão explicar as atuais mobilizações. As identidades são cada vez mais fragmentárias e fluidas, ainda que se possa sustentar que a intensidade de uma ação coletiva induza nos participantes um certo sentimento de comunhão, porém furtivo e passageiro. Se é verdade que o adversário existe (princípio da oposição), nem sempre é claro contra qual opositor cada uma destas mobilizações se define. Nuns casos, opõe-se a regimes tirânicos e aos seus representantes máximos, encontrando na figura do ditador a personificação daquilo contra o qual se luta. Noutros casos o adversário é abstrato (o capitalismo) ou é um poder localizado (a prefeitura, a câmara, o ministro X, o Governo), que pode alterar-se e remeter para outros adversários mais distantes (o governo central, o FMI, a Comissão Europeia, etc.). Finalmente, quanto ao princípio da totalidade, se o mesmo apontava para um modelo alternativo de sociedade (por exemplo o socialismo), é bem sabido que esse objetivo longínquo está longe de ser o elemento unificador dos movimentos sociais do século XXI. Enquanto uma nova utopia capaz de surgir como alternativa não se expandir, as indefinições e ambiguidades dos movimentos tendem a persistir (Cohen e Arato, 1994; Laclau, 1996; Melucci, 2001; Santos, 2003).

A questão da alternativa mudou de sentido nas últimas décadas. Por outras palavras, não é em nome do futuro que as pessoas se mobilizam, mas mais em nome da recusa de um passado humilhante ou de um presente desprezível (Arcary, 2013). E pior do que o passado (seja este radioso ou miserável) é o facto de a maioria desprezar a situação presente e começar a olhar com realismo a possibilidade de mudar de vida e enfrentar o desconhecido: o "pior do que está é impossível!" pode tornar-se uma ideia agregadora. Como realçou um conhecido especialista na matéria, "nenhum observador esclarecido e moderadamente inteligente poderia examinar o estado do planeta e concluir que haveria como repará-lo sem uma 
transformação radical" (Eagleton, 2011: 244). Outro intelectual da atualidade, Slavoj Žižek, afirmou recentemente que

a diferença entre um período reformista e um período revolucionário é que no primeiro a revolução global continua a ser um sonho que, na melhor das hipóteses, sustenta as nossas tentativas para aprovar alterações locais - e no pior dos casos impede-nos de concretizar mudanças reais -, ao passo que uma situação revolucionária surge quando se torna claro que apenas a mudança global radical pode resolver os problemas particulares. (Žižek, 2013: 101)

Dificilmente poderemos confundir os levantamentos sociais aqui em análise com revoluções no sentido atrás descrito, muito embora se saiba que, em alguns casos, como na chamada Primavera Árabe (Tunísia, Egito, Líbia), ocorreram mudanças radicais, quedas de governos e de regimes, devido à amplitude e intensidade das manifestações de rua. ${ }^{1}$ Tendo em conta a forma e os contornos que por vezes adquirem estas sublevações, e dada a pressão que colocam perante governos e instituições, pode admitir-se um potencial "revolucionário", se bem que a sua natureza difusa e a ausência de uma "alternativa" ou de uma orientação ideológica deixem em aberto o desfecho (progressista ou reacionário) dessas rebeliões. Os meios informáticos e em especial as novas "redes sociais" constituíram o ingrediente decisivo deste novo ciclo de protestos sociais.

\section{Classe média, entre o individualismo e a precariedade}

Não obstante toda a controvérsia e imprecisões teóricas a respeito do termo "classe média", ele contém um potencial heurístico. Para revelá-lo há que ter presente a origem da noção e nela buscar o porquê da sua tão profunda penetração na linguagem comum. Um texto recente, de Ezequiel Adamovski (2013), mostra que a génese da expressão (classe média) remete para uma antiga metáfora popular assente na premissa de que a organização do mundo físico contém sempre um elemento "superior", um "médio" e um "baixo". Foi isso que ajudou a disseminar um mapa mental segundo o princípio moral de que a virtude está no meio, ou seja, é a posição intermédia

\footnotetext{
${ }^{1}$ Poderá ser também o caso mais recente dos acontecimentos na Ucrânia (embora este seja mais controverso, dados os contornos que assumiu) ocorridos entre novembro de 2013 e fevereiro de 2014, em que o governo do Presidente Ianukovich foi derrubado após uma forte e persistente contestação popular que durou cerca de três meses, com a ocupação pelos manifestantes da principal praça da capital Kiev - a Praça Maidan - que culminou com dezenas de mortes, a demissão do governo, a fuga do presidente e a nomeação de um governo provisório (mas com o país, entretanto, a sofrer retaliações da Rússia e a ficar à beira da fragmentação e da guerra civil).
} 
que corresponde ao locus da justa medida, da moderação e da virtude, por oposição aos extremos (que no caso significam a situação de miséria, de um lado, e a riqueza exagerada, de outro). É nesta linha que, à luz da velha tradição liberal europeia, a ideia de civilização e de progresso se foi associando a um padrão de vida e de cultura, inscrita num certo sentido de evolução histórica, onde a classe média ocupou um papel decisivo durante o século Xx, conotando-a com o "motor da história" (a despeito da "luta de classes" ou em estreita ligação com ela), pelo menos segundo a leitura do liberalismo e da social-democracia europeia, apesar de, nos EUA, ter prevalecido o velho lema oitocentista do empreendedorismo individual (e a meritocracia) como a via a seguir para colocar a classe média tocquevilliana na senda do El Dorado.

Por outro lado, a discussão em torno do conceito de "classe média" implica que a mesma seja analisada na sua perspetiva dinâmica, sem no entanto esconder que as suas conceptualizações ao longo do século xx exprimiram visões muito díspares entre os cientistas sociais. Mais do que uma visão "essencialista" (em geral assente na ideia de homogeneidade) fundada na tradicional conceção dicotómica da luta de classes, interessa olhar as tensões internas e os processos de segmentação entre grupos e subgrupos em disputa por monopolizar recursos, poder e estatuto social, embora sem esquecer que tais processos decorrem sob a lógica do antagonismo entre capital e trabalho. ${ }^{2}$ A conflitualidade social não obedece apenas ao critério marxiano do "lugar nas relações sociais de produção" (onde a posse da propriedade privada e a transferência de mais-valia definem as relações entre as classes fundamentais), mas também a conflitos de status e estilos de vida segundo as lógicas de usurpação e distinção que persistem no seio da classe média. Este é um dos pontos em que os legados marxista e weberiano se podem enriquecer mutuamente (Parkin, 1979; Bourdieu, 1979; Eder, 2001; Burawoy, 2009).

É conhecido o papel histórico do movimento operário e do sindicalismo - bem como a promessa do "socialismo soviético" e o clima de Guerra Fria -

\footnotetext{
${ }^{2} \mathrm{O}$ objetivo deste texto não passa pela discussão aprofundada do conceito de classe social, cuja definição clássica, de Karl Marx, remete para a divisão social do trabalho e o controlo da propriedade, no modo capitalista de produção: "assalariados, capitalistas e proprietários de terras, membros das três grandes classes sociais, [...] e os seus componentes vivem respetivamente de salário, de lucro e da renda fundiária, utilizando a força de trabalho, o capital e a propriedade fundiária" (O Capital, Livro 3. Vol. 6, 2008: 1164). Para V. I. Lenine as classes sociais são "grupos de homens que se diferenciam entre si pelo lugar que ocupam num sistema historicamente definido de produção social, pela sua relação (a maior parte das vezes fixada e consagrada pelas leis) com os meios de produção, pelo seu papel na organização social do trabalho e, portanto, pelos modos de obtenção e pela importância da parte das riquezas sociais de que dispõem. As classes são grupos de homens em que uns podem apropriar-se do trabalho dos outros graças à diferença do lugar que ocupam num sistema da economia social" (Lenine, vol. I., Obras Escolbidas, t. 1, 1977: 13).
} 
para viabilizar o "compromisso histórico" (entre trabalho e capital) que abriu caminho às políticas sociais na Europa da segunda metade do século Xx - o Estado-providência - e, consequentemente, à expansão da classe média (Erikson e Goldthorpe, 1992; Esping-Andersen, 1996). Na verdade, o crescimento desta categoria nas sociedades europeias não é nem nunca foi resultado direto de uma suposta "meritocracia", mas sim das lutas e negociações persistentes (conduzidas pelo sindicalismo) desencadeadas pelos novos segmentos qualificados da classe trabalhadora, que aspiraram a mais direitos, poder de compra, carreiras e proteção social. Por isso mesmo, esses estratos correspondem a categorias "intermédias" da classe trabalhadora que consolidaram o seu estatuto à custa da luta social e, por isso, não correspondem àquela classe média "instalada" e com pretensões de elitismo que se limitou a beneficiar da herança patrimonial ou do mundo dos negócios dos seus antepassados. Todavia, decorridas cerca de seis décadas, os filhos e netos da classe trabalhadora do pós-guerra, embora beneficiários de um processo que os "elevou" a outro estatuto, vivem hoje, em boa medida, sob a ameaça de empobrecimento, encontram-se hoje numa condição ambivalente e descompensada, isto é, com qualificações e capital educacional elevados, mas recursos económicos baixos e em declínio. Tudo isto conduz à degradação do seu estatuto (Estanque, 2012) e à radicalização das suas subjetividades e posicionamento político. A velha classe de serviço (Erikson e Goldthorpe, 1992) tende, pois, a tornar-se uma classe rebelde, em especial os seus setores em processo de formação, como é o caso dos mais jovens. Sem esquecer que a juventude é, ela própria, marcadamente ambivalente, dado encontrar-se numa fase de consolidação e de vulnerabilidade na sua trajetória e babitus de classe ainda mal definidos (Pais, 1990). ${ }^{3}$

Alguns autores têm associado as transformações recentes do mercado de trabalho à emergência do precariado (Standing, 2013), categoria que incorpora segmentos significativos da classe média assalariada, cujo trabalho se tornou "frágil e instável, sujeito às contingências do mercado, à informalização, às agências de emprego, ao regime de tempo parcial, ao falso autoemprego e a esse novo fenómeno de massas chamado crowd-sourcing" (Standing, 2014: 12). ${ }^{4}$

\footnotetext{
${ }_{3}$ Além dos textos de José Machado Pais, veja-se também o texto seminal de Pierre Bourdieu (1992), "La 'jeunesse' n'est qu' un mot”, Questions de Sociologie. Paris: Éditions Minuit, 143-154 [edição orig,: 1984]. ${ }^{4}$ Aqueles a quem foram negadas as condições atribuídas ao trabalhador clássico: i) acesso ao emprego com salário estável; ii) garantia de vínculo laboral; iii) segurança e oportunidade de carreira; iv) proteção contra riscos e acidentes no trabalho; $\mathrm{v}$ ) acesso a formação profissional e treino; vi) garantia de salário estável e progressivo; vii) garantia de representação coletiva ou sindical (Standing, 2013: 27-28). "Flexitrabalhadores" ou "geração Y" (nascida depois de 1980) são apenas alguns dos rótulos desta nova legião de força de trabalho precária que usa uma linguagem nova - emails, sms, Facebook, etc. - que por vezes faz mesmo dela um "ciberproletariado" (Huws, 2003).
} 
Estas concetualizações não são consensuais nos atuais debates. Este autor, embora admitindo que o precariado possa constituir uma classe em construção, sustenta que entre esta força de trabalho vulnerável e o que designa de "salariado" (a velha categoria de trabalhadores "protegidos" do modelo industrial) há sobretudo divergência. Além disso, Standing aceita como irreversível a vulnerabilidade, instabilidade e fluidez de formas e de vínculos de trabalho, que considera "um imperativo do processo de trabalho global", e, inclusive, sugere como um cenário possível de "paraíso" a expansão do atual modelo de flexibilização e de mercadorização do trabalho, através, não da ação sindical, mas de "um novo tipo de corporação colegiada" que assuma o desafio de uma "negociação colaborante” (Standing, 2013: 252). Como é natural, essa abordagem é contrariada por visões mais marcadamente críticas do capitalismo global.

Para autores como Ursula Huwz (2003), Ricardo Antunes (2013) ou Ruy Braga (2012), a nova segmentação e recomposição do trabalho é a principal força propulsora das novas lutas sociais globais, visto que daí derivam implicações para a degradação das condições de vida e uma pauperização estrutural crescente, que se insere na própria dinâmica do capitalismo e que lhe serve de alimento. A situação do Brasil assume configurações específicas e a contestação resultou de uma combinação de fatores muito variados, colocando lado a lado ações radicais de núcleos de ativistas politizados e a presença espontânea de setores da classe média descontente. Já a nível mais geral o que está a ocorrer é uma enorme fragmentação e metamorfose da classe trabalhadora, fruto do metabolismo do capitalismo global. Em suma, quer no caso de Portugal quer no do Brasil, a recente onda de rebeliões fez confluir segmentos distintos dos referidos grupos subalternos e precarizados com outros setores da força de trabalho, expressão do novo figurino do trabalho e da luta de classes. Todavia, como atrás referi, as próprias alianças entre esses dois grandes conjuntos são igualmente precárias e pontuais (ou simplesmente não existem). Por isso mesmo, as ações de rua, por serem despojadas de lideranças e de objetivos claros, tendem a obedecer mais a impulsos e ansiedades ainda latentes do que a orientações políticas definidas. As noções de latência e de "pulsão" podem, assim, ser ajustáveis

\footnotetext{
${ }^{5}$ O termo "latência", se usado numa perspetiva biológica, pode designar um estado de repouso de um organismo, em que as funções vitais são ainda pouco evidentes antes de entrar em atividade manifesta. $\mathrm{Na}$ conceção mertoniana entre funções manifestas e funções latentes, estas foram definidas como as funções não desejadas ou não intencionais. Por sua vez, a noção de "pulsão" remete para Freud e significa a tendência instintiva mais ou menos consciente que estimula e motiva as atividades do sujeito. Se a estas noções juntarmos o conceito de habitus (Bourdieu), estaremos perante conceitos que nos ajudam a admitir a existência de uma zona "semiconsciente" da ação coletiva, que opera na penumbra dos movimentos sociais mais inorgânicos e espontâneos, onde ao mesmo tempo se revelam e escondem desejos recalcados, expectativas e necessidades não satisfeitas.
} 
a dinâmicas coletivas que, não obstante o seu impacto político, transportam também lógicas e comportamentos de multidão.

Olhando a forte mobilidade, a fluidez e a instabilidade dos trabalhadores que compõem o precariado é forçoso reconhecer uma diferença abissal em comparação com o "velho" proletariado da Inglaterra do século XIX, estudado por F. Engels (2008 [1842]) e E. P. Thompson (1982 [1963]), considerando as suas experiências e formas de convivialidade, que induziram a cultura de resistência e a consciência da classe trabalhadora nas suas lutas contra o capitalismo emergente. Daí que, mesmo reconhecendo a natureza estrutural da condição precária do século XXI, é necessário atender à profunda reconfiguração das condições de trabalho para compreender a incongruência entre a composição da atual classe trabalhadora (mais qualificada e mais precária) e a sua expressão no terreno sociopolítico.

Mas o entendimento destas novas tendências requer que se olhe para o passado recente. Com o fim do fordismo e dos trinta anos gloriosos, tornou-se claro que, na Europa ocidental, a promessa de "mobilidade social ascendente" da classe trabalhadora, fundada na "meritocracia", foi uma falácia. Com efeito, as lutas sociais do século xx não foram somente fruto da "vanguarda" operária, mas também dos "beneficiários" do Estado de bem-estar, incluindo todo um conjunto de novas categorias socioprofissionais (professores, médicos, quadros da administração pública, etc.). Na sua obra clássica Middle Class Radicalism (1968), Frank Parkin identificou diversos grupos dentro da classe média, mostrando a importância em especial dos setores da classe média educada ${ }^{6}$ na participação no movimento ambientalista de finais da década de 1960 (Parkin, 1968: 177). Se é verdade que no pós-68 o capitalismo ocidental não deixou de revelar toda a sua capacidade regeneradora, tais movimentos abriram espaço a novos valores, novos reportórios, dimensões e modalidades inovadoras de ação coletiva (Eder, 2001; Boltanski e Chiapello, 2001; Estanque, 2012).

Importa, porém, atender às especificidades de cada país. Portugal, como sabemos, sofreu com o atraso na industrialização e a abertura democrática tardia, enquanto o Brasil foi marcado ainda por outro tipo de fatores

\footnotetext{
${ }^{6}$ Para Frank Parkin o capital educacional é um fator importante, sendo no entanto necessário distinguir entre dois segmentos: de um lado os empregados inseridos no mundo dos negócios e do comércio (seguros, banca, marketing, executivos técnicos, vendedores e supervisores de empresas privadas, etc.); e de outro os inseridos em atividades viradas para o bem-estar, a educação e profissões criativas (por exemplo serviço social, serviços de saúde, ensino, jornalismo, profissões científicas, etc.). Enquanto nos últimos existe uma primazia da noção de serviço à comunidade, na melhoria da condição humana ou na expressividade e criatividade, os primeiros estão enquadrados por valores do mundo dos negócios, influenciados por uma preocupação sobredirecionada para o lucro e a eficiência, cujas recompensas são principalmente de natureza material ou monetária (Parkin, 1968: 180).
} 
históricos e socioculturais, designadamente pelo legado do colonialismo. Daí que, hoje como ontem, a discussão sobre a estrutura de classes e a controvérsia em torno da classe média brasileira requeira outras referências. Primeiro, a herança colonial e a presença histórica de escravatura deixaram marcas indeléveis. Depois, a emergência tardia da classe média estabelecida ${ }^{7}$ beneficiária direta das políticas governamentais do Estado, sobretudo no período varguista e do chamado "milagre económico" brasileiro (1968-1973). Este segmento privilegiado das classes média e média-alta (sobretudo as que se concentram na cidade de São Paulo) é herdeiro de um estatuto social e de uma subjetividade conservadora que tende a "naturalizar" a sua (real ou imaginária) posição junto da elite. É esse legado que justifica a sua atitude preconceituosa em relação aos novos segmentos emergentes e aos estratos sociais mais pobres ou excluídos, que são, afinal, os principais alvos de uma estigmatização, de um "racismo de classe", que ainda hoje se torna chocante aos olhos de qualquer visitante que circule pelo centro de uma cidade como São Paulo (Guimarães, 2002; Santos, 2004; Souza, 2010).

Quer isto dizer que essa é apenas uma "subcategoria" dentro da classe média (com elevado capital económico e capital cultural e educacional com pouca solidez), à qual podemos opor as novas "subcategorias" emergentes, com elevado capital educacional e baixos recursos económicos. Assim, aos velhos anátemas lançados contra a classe média, tais como o seu intrínseco "individualismo" e "emburguesamento", pode contrapor-se um radicalismo de classe média. Um radicalismo que no passado se exprimiu nos movimentos estudantis e ambientalistas dos anos sessenta (Barker, 2008; Estanque e Bebiano, 2007) e que, nos últimos anos, se traduz na crispação contra um bloqueio asfixiante das oportunidades e na busca de um Estado social por construir e um desenvolvimento económico eternamente adiado.

As tipologias de análise de classes continuam em reatualização e têm surgido novas e interessantes propostas, nomeadamente sob influência do pensamento weberiano e "bourdieuano" (Savage et al., 2013; Souza, 2010), ${ }^{8}$

\footnotetext{
7 Aquela que, regra geral, é referida no senso comum académico como a própria classe média. Ficou célebre a frase de Marilena Chauí (em tom exaltado): "A classe média é uma abominação política, porque é fascista, é uma abominação ética porque é violenta, e é uma abominação cognitiva porque é ignorante." Debate "A Ascensão Conservadora em São Paulo", com a participação de André Singer e Vladimir Safatle, moderado por Ricardo Musse. USP, 28.08.2012.

${ }^{8}$ Refiro-me a um estudo recente apoiado num amplo inquérito aplicado às classes sociais do Reino Unido, o BBC’s Great British Class Survey, na base de uma amostra de 161400 inquiridos. Os autores usam uma tipologia de sete categorias, onde a dita "classe média" surge segmentada na base de diversas variáveis socioeconómicas e culturais (capital económico, social e cultural/ educacional), ou seja, onde o conceito de classe social é tomado como um constructo multidimensional, que comporta aspetos económicos, elementos simbólicos e formas de reprodução social e de distinção cultural.
} 
mas o valor heurístico da noção de classe média pressupõe situá-la no quadro de processos políticos e discursivos mais profundos, capazes de fazer com que determinados conjuntos de pessoas se agrupem com outros, ainda que ocupando diferentes condições socioprofissionais (Adamovski, 2013: 48).

\section{Portugal e a proletarização da classe média}

Num estudo conduzido por Nuno Nunes (2013), utilizando dados do European Social Survey (ESS) e baseado na tipologia de classe da equipa do ISCTE-IUL, ${ }^{9}$ considerou-se o tipo de vínculo laboral cruzado com a categoria de classe, a fim de avaliar o nível de precariedade segundo a variável classe. Conclui-se que a posição mais vulnerável quanto à situação profissional é a dos Empregados Executantes (EE) ${ }^{10}$ (veja-se Gráfico 1, abaixo). Esta categoria, juntamente com os Profissionais Técnicos e de Enquadramento (PTE), corresponde a segmentos socioprofissionais qualificados, que no passado recente detinham uma posição estável nas fileiras da classe média assalariada. Estes são, com efeito, os setores que mais viram reforçado o seu peso estatístico entre a população portuguesa empregada nos últimos cinquenta anos em Portugal, evoluindo de 14,6\% para 36,4\% e de 2,6\% para 22,5\% entre 1960 e 2011 (Carmo, 2013). Como se pode observar, os vínculos precários (contratos a termo certo, falsos recibos verdes e trabalho a tempo parcial) atingem não apenas os operários manuais (categoria "O"), mas também a "pequena burguesia técnica e de enquadramento" (PTE) e os "empregados executantes" (EE). Note-se que Portugal é o país onde, em termos relativos, os "Empregados Executantes" (EE) são a categoria mais atingida por condições de trabalho precárias. ${ }^{11}$

\footnotetext{
${ }^{9}$ Equipa composta por João Ferreira de Almeida, António Firmino da Costa e Fernando Luís Machado.

${ }^{10}$ Esta categoria é, com efeito, a que revela maior presença de trabalho precário, incluindo os contratos de trabalho a termo certo, a tempo parcial ou situações de subcontratação através das empresas de trabalho temporário, ou ainda os falsos recibos verdes.

${ }_{11}$ Quanto ao peso relativo destas categorias - Dirigentes e Profissionais Liberais (DPL), Profissionais Técnicos e de Enquadramento (PTE), Empregados Executantes (EE), Operários (O) e Assalariados Agrícolas (AA) -, verifica-se que os PTE evoluíram de 3,8\% da população ativa empregada em 1985 para $17,8 \%$ em 2009, os EE passaram de $36,1 \%$ em 1985 para $42,3 \%$ em 2009 , e os operários reduziram o seu peso de $56,4 \%$ para $33,7 \%$ no mesmo período; finalmente os DPL, que correspondiam em 1985 a 1,5\% dos trabalhadores, passaram a 4,1\% em 2009. Em relação à distribuição do rendimento, a categoria DPL (mais próxima da elite) é a que aufere maiores rendimentos, correspondendo a um segmento que se qualificou e feminizou significativamente em Portugal, além de ter aumentado o volume de profissionais. No entanto, o seu ganho mensal, segundo o referido estudo, aumentou significativamente entre 1995 e 2005, decrescendo a partir de então até 2007, e estabilizando depois (em 2009 o salário médio mensal era de 2 277,00 euros).
} 
Isto parece indicar que o processo de fragmentação do trabalho e de flexibilização tem atingido não só as camadas tradicionais da força de trabalho manual, mas também setores da classe média assalariada e trabalhadores dos serviços, que se tornaram um alvo primordial das medidas de redução de custos das empresas.

Parece, portanto, evidente que no caso português (assim como na Estónia, Eslovénia e Suécia) os segmentos da "classe média" são aqueles onde mais incidem os vínculos precários de trabalho, o que significa que se trata de uma camada - próxima do precariado - que praticamente foi excluída da cidadania laboral nos últimos anos, visto corresponder a um segmento "sem condições para desenvolver o lazer e intervir politicamente [...] porque perdeu o sentido de segurança." (Standing, 2009: 314).

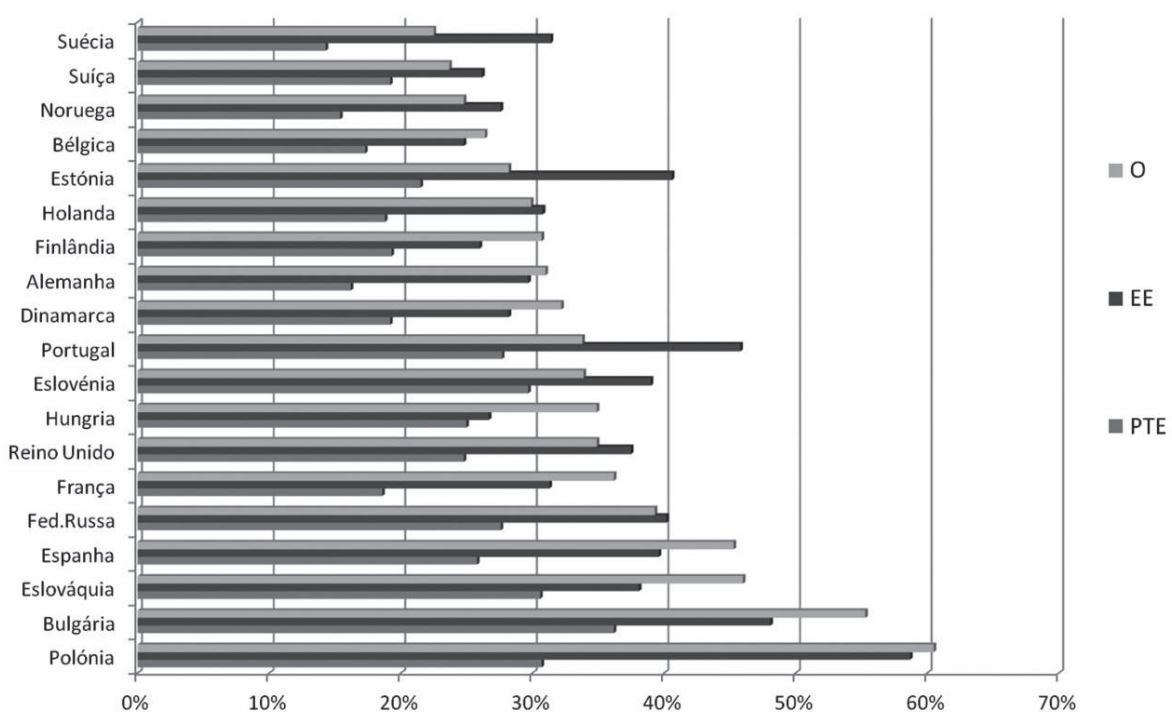

GRÁFICO 1 - Segmentação do trabalho e precariedade, por categorias de classe na UE Fonte: ESS - European Social Survey (2006), in Nuno Nunes (2013: 127).

Há certamente uma estreita relação entre a precariedade e a condição de classe, ou seja, a "reforma" imposta de cima para baixo sobre o sistema de emprego interfere diretamente na coesão social e atinge violentamente as condições laborais, o mercado de trabalho e a vida das famílias e dos cidadãos. Daí que o efeito das políticas de austeridade se esteja a fazer 
sentir sobre as desigualdades sociais desde $2009,{ }^{12}$ contrariando o ciclo anterior, que teve uma evolução positiva desde a década de 1990 até esse ano. Considerando o critério de Ursula Dallinger (2011), estabeleceu-se a distribuição do rendimento monetário disponível por adulto equivalente (rendimento familiar) ${ }^{13}$ pelos cinco quintis da população, donde ressalta que nos três quintis do meio (correspondendo às classes médias) houve um aumento do rendimento desde a década de 1970, que se reforçou no inicio deste século. No entanto, a partir do ano de 2009, quando a crise se agudizou no nosso país deu-se uma inversão: "entre 2009 e 2010 a porção do rendimento total detido pelos $5 \%$ e $10 \%$ mais ricos em Portugal aumentou 0,8 e 0,6 pontos percentuais, respetivamente" (Cantante, 2013: 137). Usando como referência o salário mediano ${ }^{14}$ - que era em 2009 de apenas 741,00 euros (brutos) - pode dizer-se que se, por exemplo, considerarmos a "classe média" como a camada situada no intervalo económico 75\%-150\% do ganho mediano, teremos nesse segmento $51,4 \%$ dos assalariados portugueses (ibidem: 141).

Porém, a reestruturação do sistema de emprego nas últimas décadas já vinha revelando uma forte presença de trabalhadores vulneráveis, que alguns autores classificaram de novos proletários (Antunes, 2013). Em meados da década de 1990, uma categoria que num estudo anterior designei por "proletários" revelava um peso de 46,5\%, número que em 2001 desceu para $31 \%$ da força de trabalho portuguesa (Estanque e Mendes, 1997; Estanque, 2003). Tal tendência parece ir ao encontro da ideia de que em Portugal a classe média era frágil e, por isso, mais facilmente entrou em declínio (Estanque, 2012). Desde a década de 1990 que, com a globalização económica e a força

\footnotetext{
${ }^{12}$ Estudos recentes mostram que na primeira década deste século os níveis de desigualdade em Portugal reduziram ligeiramente, embora na comparação com a UE27 o país permanecesse entre os mais desiguais. Até ao culminar da presente crise, o crédito fácil, fortemente estimulado pelo sistema financeiro internacional e pelas baixas taxas de juro, compensou artificialmente a quebra real de salários, permitindo às famílias manter estilos de vida e níveis de conforto segundo um horizonte de expectativas positivas para o futuro (Carmo, 2013: 152-153). Todavia, dados mais recentes mostram que o rendimento anual mediano, por adulto, em Portugal continua muito abaixo das médias dos países europeus. Em 2009 cerca de 75\% dos portugueses auferiam rendimentos inferiores a 12625 euros/ano (1052,1 euros mensais), com Portugal a posicionar-se no quarto lugar entre os países com maiores desigualdades e onde se praticam dos salários mais baixos da zona euro. Além disso, os níveis salariais dos segmentos intermédios diminuíram nos últimos anos. O que significa que 2009 foi um ano de inversão da tendência anterior, visto que esse foi o momento inicial de agudização da crise e da austeridade (ibidem: 137).

${ }^{13}$ Os critérios do Eurostat (EU-SILC) usam a Escala de Equivalência Modificada da OCDE, em que o primeiro adulto do agregado (com 14 anos ou mais) tem um peso de 0,1 , os restantes adultos têm um peso de 0,5 , e as crianças com menos de 14 anos têm um peso de 0,3 .

${ }^{14}$ Ou seja, o valor situado no meio, em que metade da população ganha abaixo e a outra metade ganha acima desse valor.
} 
crescente do neoliberalismo, o modelo europeu e o Estado social vinham sendo postos em causa, atingindo em primeiro lugar os direitos laborais. O aumento do desemprego, os contratos precários, a subida de impostos, o congelamento de carreiras e salários na função pública, a privatização de serviços e de património público, as medidas de contenção impostas na saúde, na educação, na ciência, etc., já há muito vinham sendo denunciadas como um retrocesso nas conquistas da democracia, e, por isso, grande parte dos portugueses as vinham contestando, mesmo antes da chegada da crise mais violenta. Mas foi sobretudo nos últimos anos que a conflitualidade social mais se acentuou. Entre 2010 e 2012 ocorreram em Portugal 384 greves envolvendo cerca de 224500 trabalhadores (apenas no setor privado). ${ }^{15}$ A intensidade do descontentamento disparou sobretudo durante a vigência do programa de resgate - assinado pelos três partidos do arco do poder, PS, PSD e CDS -, que impôs aos portugueses este modelo de "sociedade da austeridade" (Ferreira, 2012).

Muito embora os movimentos sociais "inorgânicos" obedeçam a uma lógica que os afasta do campo sindical, não se deve, portanto, minimizar a importância do sindicalismo na resistência da "sociedade civil" contra as políticas de austeridade (Estanque e Costa, 2011). A tensão existente entre esses dois mundos não invalida a conexão e contaminação recíproca entre eles. Dito de outro modo, a influência do campo sindical na consciencialização social dos cidadãos não implica a adesão consciente destes às propostas e formas de ação daqueles.

Um estudo recente - conduzido por uma equipa do Instituto de Ciências Sociais (ICS) da Universidade de Lisboa - indicava, inclusivamente, que são poucos os portugueses que se sentem representados nos sindicatos $(10 \%)$ ou nos partidos políticos (também 10\%), embora os movimentos sociais também não obtivessem a confiança de muitos mais (12\%) (Pinto et al., 2013). Quanto às atitudes, os últimos levantamentos mostraram a discrepância entre a "importância" e o "desempenho", como foi o caso dos recentes resultados do European Social Survey de 2012-2013, divulgados pelo Instituto de Ciências Sociais (ICS, Lisboa, 18.03.2014), onde Portugal revelou existir um fosso entre a importância atribuída pelos cidadãos às instituições democráticas e a avaliação que fazem do seu desempenho, o que fica bem claro no que respeita, por exemplo, a tópicos como o funcionamento dos tribunais, o combate à pobreza e às desigualdades sociais.

${ }^{15}$ Valores referentes apenas ao setor privado. Fonte: DGAEP-Direção Geral da Administração e do Emprego Público, 2014. Veja-se, neste volume, o artigo de Hermes Augusto Costa, Hugo Dias e José Soeiro: "As greves e a austeridade em Portugal: olhares, expressões e recomposições". 


\section{Um novo ciclo de manifestações em Portugal e na Europa do Sul}

É a esta luz que importa identificar os fatores sociológicos que estão na raiz da vaga de manifestações que ocorreram em Portugal entre 2011 e 2013. À escala global os vários acontecimentos deste último ciclo de rebeliões exprimem como características comuns o facto de serem, como se referiu, marcadamente dinamizadas pelas camadas da juventude escolarizada, veiculadas através do ciberespaço, marcadas pela organização flexível, em rede, sem lideranças identificadas e, ainda, revelarem um caráter parcialmente espontâneo. A exposição mediática - nomeadamente através do ciberespaço - faz com que as imagens e o aparato dramático das multidões em revolta, ou a festa coletiva de um desfecho vitorioso, possam desencadear um efeito mimético de rápida propagação internacional.

Em 12 de março de 2011 ninguém esperava tanta afluência à primeira grande manifestação da chamada "Geração à Rasca". O descontentamento face aos partidos e a democracia representativa era bem visível: "precários nos querem, rebeldes nos terão!"; "queremos as nossas vidas!”; "roubo do salário!”; "o país está à rasca!”; "economia rasca, basta!”; "precários não são otários!"; "o povo unido não precisa de partido!"; "rasca é a precariedade"; "não me obriguem a emigrar"; "eu quero ser feliz"; "quem elegeu os mercados?", entre muitos outros, foram alguns dos slogans mais gritados em Lisboa e no Porto. Um jornal do dia afirmava: "Cartazes com as palavras 'flexitanga' e cravos vermelhos também marcam o protesto. [...] as imagens das televisões mostram um mar de gente na Avenida da Liberdade" (jornal Expresso, 12.03.2011). Em Lisboa a organização indicou a presença de cerca de 200 mil manifestantes e de 80 mil no Porto.

Esse foi um momento alto dos movimentos de protesto em Portugal. Marcou uma viragem em que o campo sindical deixou de ter o exclusivo da luta social e laboral, e talvez por isso tenha marcado momentaneamente o debate público. Dois meses depois, os Indignados e as Acampadas da Democracya Real Já, na Puerta del Sol em Madrid - Espanha, transmitiram mensagens de conteúdo semelhante e não deixaram de invocar o exemplo português (Velasco, 2011); e logo depois a onda global de contestação em torno do movimento Occupy Wall Street, centrado em Nova Iorque mas que teve uma influência mundial (Taylor et al., 2011; Harvey et al., 2012). Em Portugal, pode resumir-se este ciclo, por ordem cronológica: o 15 de outubro de 2011 (Dia de Ação Global), a greve geral de 24 de novembro de 2011 (organizada conjuntamente pela CGTP e pela UGT), as concentrações de 12 de maio de 2012 (Primavera Global), o 15 de setembro de 2012 (Que se Lixe a Troika), o 13 de outubro de 2012 (protestos culturais do movimento de artistas ligados ao Que se Lixe a Troika) e a greve geral com 
dimensão europeia de 14 de novembro de 2012 (que ocorreu em Portugal, Grécia, Espanha, Malta e Chipre); em 2013 a manifestação do 3 de março (sob o lema da famosa canção Grândola Vila Morena, o Povo é Quem mais Ordena), ao que se seguiu uma vaga de ações promovidas por grupos de jovens organizados, as chamadas "Grandoladas", que incluíram iniciativas de boicote a atos oficiais com a presença de representantes do Governo, em que o público interrompia os discursos com a referida canção cantada em coro ou gargalhadas coletivas, destinadas a atrapalhar o discurso desses personagens, sendo que o ex-ministro Miguel Relvas foi o alvo privilegiado (Soeiro, 2014).

Para além desses momentos de luta mais intensos (que começaram ainda no Governo de José Sócrates), importa recuar pelo menos uma década para situar o início da derrocada de muitas das ilusões da classe média portuguesa. Até às sucessivas e cíclicas mobilizações sindicais, greves e lutas laborais de cariz corporativista - onde pontuaram, designadamente, os professores, funcionários públicos, médicos, enfermeiros e trabalhadores do sistema de saúde, ou seja, aqueles segmentos socioprofissionais de "classe média" - suportadas por esses setores, que se foram tornando a principal base de apoio do campo sindical, à medida que o velho operariado foi perdendo peso e combatividade e o sindicalismo se foi institucionalizando e burocratizando. Porém, a mais recente vaga de protestos não só continuou a ter como principal causa o mundo do trabalho, como imprimiu um novo fôlego à ação coletiva nesse campo (Estanque, Costa e Soeiro, 2013).

\section{Brasil: a classe média, o mercado de trabalho e a "blindagem" do sistema político}

Com a entrada no novo milénio, e em especial a partir de 2003, o Brasil começou a evidenciar uma melhoria nos indicadores do mercado de trabalho e da economia. O ritmo de crescimento económico foi, em média, de $5,4 \%$ até 2008 , e de $5,5 \%$ em 2009 e 2010. Por seu lado, o nível salarial continuou a crescer a ritmos superiores à inflação (Krein e Baltar, 2013). Pode dizer-se que a ampliação do programa Bolsa Família, com os aumentos reais do salário mínimo e com o subsídio ao crédito popular, interagiram com o crescimento económico, ajudando a fortalecer o mercado de trabalho e o aumento do consumo. Entre 2003 e 2010, foram criados em média 2,1 milhões de empregos formais por ano, na sua esmagadora maioria no setor dos serviços, o que permitiu o crescimento de um discurso, eufórico e recorrente na comunicação social, em torno do crescimento da "nova classe média", aplaudido por uns e criticado por outros (Pochmann, 2012; Bartelt, 2013). 
A avaliar pelos critérios oficiais, ${ }^{16}$ esta "classe média" brasileira - medida com base no rendimento familiar e no consumo - corresponderia no ano 2000 a 31,7\% das famílias, enquanto a sua capacidade de consumo era calculada em 50\% de todo o mercado consumidor do Brasil. Em 2012, segundo um estudo do Datafolha, os seus diferentes estratos (classe média-alta, classe média intermediária e classe média baixa $)^{17}$ correspondiam a $63 \%$ da população ativa. Todavia, embora seja evidente que o nível de poder aquisitivo dos estratos mais baixos e intermédios da pirâmide social brasileira subiram, essa é uma conclusão enganadora. As pesquisas elaboradas pela Fundação Getúlio Vargas (FGV) e pelo IPEA ${ }^{18}$ sob a liderança de Marcelo Neri (2012) apoiam-se num discurso que faz abertamente a apologia do consumismo e das virtudes do marketing e do endividamento, enquanto, por outro lado, confunde, como acabei de referir, "classes sociais" com categorias de rendimento. ${ }^{19}$ As infraestruturas materiais e condições efetivas de qualidade de vida (salubridade, conforto, educação, assistência na saúde, etc.) das famílias não são consideradas relevantes nestas tipologias.

Pode dizer-se que a pirâmide social brasileira se renovou, mas ela renovou-se mantendo a instabilidade e a precariedade no emprego. "Na década de 2000, a cada vaga aberta de emprego assalariado informal, três outras eram criadas para o trabalho com carteira assinada" (Pochmann, 2012: 38). Para além disso, a taxa de rotatividade (em cerca de $37 \%$ do emprego formal, em 2009) cresceu muito, sobretudo para os empregos de mais baixos salários (85,3\% para a faixa que ganha até 2,5 salários mínimos), sendo mais elevada para as camadas mais jovens. Para essas camadas, o poder de compra melhorou, os direitos foram em parte reconhecidos e o acesso à educação

\footnotetext{
${ }^{16}$ A definição oficial de classe média apoia-se na escala tradicional A, B, C, D e E; foi inicialmente definida pela Secretaria de Assuntos Estratégicos da Presidência da República (SAE). O critério é unicamente o do nível de rendimento: a classe média inclui pessoas com renda familiar per capita entre $\mathrm{R} \$ 291,00$ e $\mathrm{R} \$ 1019,00$, o equivalente a 54\% da população brasileira. As subdivisões seriam: baixa classe média, com rendimento per capita entre $R \$ 291$ a $R \$ 441$; média classe média, com ganho entre $\mathrm{R} \$ 441$ a $\mathrm{R} \$$ 641; e classe média alta, com rendimento entre $\mathrm{R} \$ 641,00$ a $\mathrm{R} \$ 1019,00$. (NB: o câmbio entre o euro e o real é de $1,00 €=3,10 \mathrm{R} \$$ nesta data, 06.05.2014).

${ }_{17}$ Segundo esse estudo, os diferentes estratos da sociedade brasileira - definidos neste caso segundo uma tipologia que combina rendimento familiar com educação e padrão de consumo - evoluíram do seguinte modo entre 2001 e 2011: classe alta de 10\% para 9\%; classe média-alta de $17 \%$ para $19 \%$; classe média intermediária de $17 \%$ para $26 \%$; classe média-baixa de $23 \%$ para $18 \%$ (separata especial do jornal Folha de São Paulo, 22.01.2012).

18 O Instituto de Pesquisa Económica Aplicada (IPEA) é uma fundação pública federal vinculada à Secretaria de Assuntos Estratégicos da Presidência da República.

19 Veja-se a este propósito o texto "O politburo ortodoxo", Carta Capital, n. ${ }^{\circ}$ 772, de 30.10.2013, pp. 36-37, onde o referido especialista é apresentado como um dos mais eminentes representantes do paradigma neoliberal no seio do governo do PT.
} 
também evoluiu; e tudo isto combinado contribui para estimular a cidadania e multiplicar as aspirações pessoais e familiares.

As variáveis sociais são inseparáveis da esfera política, pelo que importa ainda assinalar outras especificidades da jovem democracia brasileira que poderão ajudar a entender os protestos. Os movimentos sociais e sindicais da década de 1980 radicalizaram a tal ponto as revoltas populares no Brasil que, inclusive, a promessa de uma democracia representativa de tipo ocidental deixara de ser suficiente para tranquilizar o povo. Perante a força coletiva da classe trabalhadora, o sistema político brasileiro viu-se na necessidade de criar mecanismos de "blindagem" que permitissem forjar maiorias parlamentares suficientemente imunes à "voz das ruas", o que conduziu a uma estratégia de alianças "contra natura" entre um leque partidário muito diversificado. Essa foi a resposta do sistema às manifestações que em 1990-1991 levaram ao impeachment de Fernando Collor de Melo; mas um tão grande ímpeto pareceu, a dado momento, pôr em perigo a legitimidade do Parlamento. E isso assustou a elite dirigente. Assim, foi-se desenvolvendo uma prática de negociações subterrâneas, que incluíam operações que iam desde a mera troca de favores (e de votos entre bancadas "rivais") a formas de corrupção e promiscuidade mais graves. Essa prática levou alguns analistas, como Marcos Nobre, a designá-la de "pemedebismo", por ter sido inicialmente desencadeada pelo PMDB. ${ }^{20}$ Trata-se de uma lógica de "centrão" forjada a partir de 1993 para reforçar o "arco da governabilidade". Esse processo desenvolveu-se e consolidou-se ao longo dos governos de Fernando Henrique Cardoso ${ }^{21}$ mas o próprio PT, após uma década de combate "antipemedebismo", repetiu o mesmo figurino na sequência do

${ }^{20}$ O PMDB - Partido do Movimento Democrático Brasileiro é herdeiro direto do MDB - Movimento Democrático Brasileiro, criado em 1965-1966 e que foi a principal força de oposição democrática durante a Ditadura Militar. Se o ex-MDB já era conhecido pela sua enorme capacidade de reunir gente dos mais diversos campos ideológicos, o atual PMDB (fundado em 1980) jamais renegou essa fama, antes pelo contrário, reforçou-a, daí o título de "partido pega-tudo" que lhe é atribuído.

${ }^{21}$ Em 1986, o PMDB promoveu a Aliança Democrática que elegeu Tancredo Neves, dando lugar a uma maioria na Assembleia Nacional Constituinte (baseada num acordo com o PFL - Partido da Frente Liberal), que então consolidou a lógica de "centrão", destinada a neutralizar as reivindicações populares: "Por um lado, esse processo mostrou que as ruas queriam retomar o poder que achavam ter sido usurpado, mal utilizado. De outro lado, pelo sistema político, houve certo pânico. Lembrando que tivemos uma transição 'morna' para a democracia, pactuada pelas elites. No momento do impeachment, essas elites, que pactuaram a transição, 'disseram': 'como faremos para nos proteger contra isso, porque não é possível que toda a hora que um presidente for mal, as pessoas irão às ruas e retiram o mandato'. [...] Daí nasceu o mito das 'supermaiorias', de que é necessário, para qualquer governo se manter e não sofrer impeachment, construir não só a maioria, mas a supermaioria, alguma coisa que atinja para além dos três quintos de votos necessários para fazer reformas constitucionais. Assim, o sistema político podia continuar operando como sempre e, ao mesmo tempo, com o fato de que os governos eleitos estariam presos a essa supermaioria, todo presidente teria a obrigação de fazer um pacto com esse sistema político" (Nobre, 2013b: 9; cf. Nobre, 2013a). 
início do escândalo do "mensalão", em 2005. "Vendo-se acossado pelo fantasma do impeachment, Lula aderiu à ideia pemedebista de construção de supermaiorias parlamentares, desenvolvendo as ferramentas de blindagem, cujo uso continuou de maneira ainda mais ostensiva sob a presidência de Dilma Rousseff, a partir de 2011” (Nobre, 2013b: 12-13).

\section{As rebeliões sociais de junho de 2013}

As manifestações de junho têm, como é evidente, uma raiz multicausal, remetendo para forças e conexões situadas em diferentes níveis de análise, do contexto local às escalas estadual, nacional e global. No início daquele mês, a situação na cidade de São Paulo (SP) começou a deteriorar-se quando, na sequência da decisão do município de aumentar o custo dos transportes urbanos (de $\mathrm{R} \$ 3,00$ para $\mathrm{R} \$ 3,20$ ), os jovens do Movimento Passe Livre (MPL) convocaram manifestações para o centro da cidade contra essa medida. O efeito imediato começou por ser a violência policial enquadrada por declarações das autoridades locais que acusaram os manifestantes de "vândalos" e ameaçaram não ceder. Esses dois fatores - a violência e as infelizes declarações do Prefeito (Fernando Haddad/ PT) e do Governador (Geraldo Alckmin/ PSDB), num contexto em que os faraónicos investimentos na construção de estádios de futebol para o Mundial de 2014 já vinham acicatando o descontentamento popular - constituíram os detonadores iniciais dos protestos que varreram o Brasil nos meses de junho e julho de 2013. Das reivindicações do MPL rapidamente se evoluiu para a luta contra a "corrupção", a exigência de uma "reforma política" e de sistemas de saúde e de educação públicas de qualidade, isto é, saúde e educação "padrão FIFA", como se gritou nas ruas.

No dia 13 de junho na Avenida Paulista em SP a primeira grande manifestação (segundo o Datafolha) ${ }^{22}$ mobilizou um maior volume de pessoas com ensino fundamental ou médio (secundário), com $76 \%$ do conjunto desses dois níveis de ensino, enquanto quatro dias depois (17 de junho), no Largo da Batata, estiveram sobretudo universitários (77\%), contra apenas $22 \%$ do ensino secundário. No dia 17 de junho $71 \%$ das pessoas participavam pela primeira vez numa manifestação, um dado bem revelador da fortíssima presença

\footnotetext{
${ }^{22}$ As fontes utilizadas foram o Datafolha, com inquéritos realizados pelos técnicos do jornal Folha de S. Paulo em diversas manifestações ao longo do mês de junho (dias 16, 18 e 20 de junho e 20 de julho), o Instituto Brasileiro de Opinião e Estatística (IBOPE) e a empresa de sondagens Clave de Fá, com base em amostras da ordem dos 2000 inquiridos. Nesta sondagem, o "IBOPE Inteligência" ouviu 2002 manifestantes em oito capitais brasileiras (São Paulo, Rio de Janeiro, Belo Horizonte, Porto Alegre, Recife, Fortaleza, Salvador e Distrito Federal) no dia 20 de junho. A margem de erro é de dois pontos percentuais e o intervalo de confiança é de $95 \%$. Consultado a 12.03.2014, em http://www.ibope.com.br/pt-br/noticias/Paginas/89-dos-manifestantes-nao-se-sentem-representados-por-partidos.aspx.
} 
da juventude nos protestos. Porém, segundo a sondagem do Datafolha, nas manifestações do dia 20 de junho acentuou-se significativamente o peso da educação universitária: a esmagadora maioria dos manifestantes (78\%) eram jovens com ligação ao ensino superior (sobretudo o setor privado) e $20 \%$ com o ensino secundário; e quanto às camadas etárias, $81 \%$ tinham idades abaixo dos 36 anos. Estes dois indicadores são a meu ver bem ilustrativos da presença de segmentos de uma emergente classe média educada e juvenil, se bem que o vínculo ao mundo laboral e a proveniência de bairros habitacionais periféricos deixem antever a forte ligação a uma classe trabalhadora mais qualificada, mas também mais precarizada e, hoje, em rápida em recomposição.

As zonas residenciais dos participantes variaram também ao longo do tempo: enquanto na primeira manifestação em SP (13 de junho) prevaleceu uma maioria de residentes da zona Leste (a mais pobre), com 38\%, contra $32 \%$ da zona Sul e $10 \%$ da zona Oeste (ambas zonas ricas e de classe média-alta), dias depois, a 17 de junho, a maioria dos participantes era oriunda da zona Oeste, com $30 \%$, seguida da zona Sul, com $26 \%$ e apenas $12 \%$ da zona Leste. Ou seja, claramente, a tendência de massificação dos protestos foi acompanhada de uma maior presença de jovens dos estratos sociais mais próximos dos estilos de vida e valores da classe média menos politizada e mais "individualista" (curiosamente nos dias em que se detetaram sinais de violência contra grupos e símbolos de esquerda entre os manifestantes), isto é, à medida que a vaga de protestos foi ganhando amplitude e intensidade, cresceu a influência de forças conservadoras (e essencialmente antipolíticas sociais) da "classe média estabelecida" e da comunicação social.
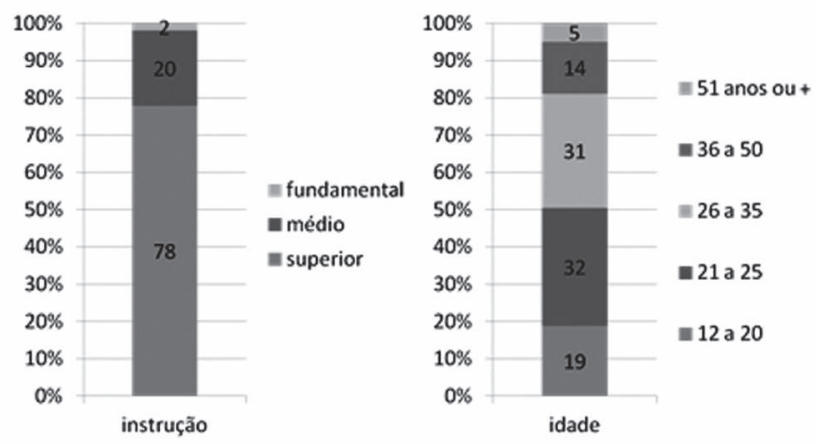

GRÁFICO 2 - Manifestações - 20 de junho de 2013, São Paulo

Fonte: Datafolha (veja-se ainda a Pesquisa CNI-IBOPE, Julho/2013, disponível em http://www.ibope.com.br/pt-br/noticias/Documents/CNI_IBOPE_edicao\%20especial_jul2013_web.pdf). 
Isso mesmo é confirmado pelas sondagens desse período (Datafolha, 27-28 de junho e 11 de setembro de 2013), onde os moradores da cidade de SP estiveram em larga maioria solidários com os manifestantes, e mesmo ao longo dos meses seguintes, até setembro, manteve-se uma atitude favorável da população de São Paulo (61\% em junho e 52\% em setembro), subscrevendo a opinião de que as manifestações "trouxeram mais benefícios do que prejuízos", a ilustrar a tentativa de "instrumentalização" dos protestos, atrás referida, por setores da direita (Datafolha, sondagens nos dias 18 e 21 de junho e 11 de setembro). Refira-se, por fim, que as formas de mobilização passaram essencialmente pelo Facebook (62\%) e outros meios da Internet (29\%).

No que se refere às orientações, aos meios mobilizados e às motivações, pode dizer-se que na era das comunicações virtuais existe uma materialidade das relações imateriais e isso refletiu-se nestes aglomerados. As comunidades de convívio e de proximidade física tendem a misturar-se cada vez mais com as redes do mundo eletrónico em que o uso do ipod, dos tablets, dos computadores ou dos telemóveis funciona como uma teia de significados múltiplos e grupos de identificação - em parte reais e em parte fictícios e de "pertença", substituindo-se ou complementando os laços de sociabilidade primária. As ligações às redes virtuais são simultaneamente fatores de integração na coletividade e veículos de afirmação e performance pessoal, onde o "eu" construído e projetado no "outro virtual" se confunde e readapta conforme a máscara que melhor se ajuste a cada esquina da ampla comunidade virtual-real. O sentido da participação na manif exprime-se na infinidade de imagens, fotos e vídeos captados e difundidos em tempo real através da rede social do Facebook e de outros meios de comunicação (incluindo a televisão). E aqui, a estética dos adornos, as cores do cartaz improvisado ou o perfil da máscara revertem-se no simulacro de um ato de bravura e de radicalismo, no qual se inscreve, no mesmo gesto, o "eu" e o "nós" (qual deles o mais fugaz). As ruas e praças de São Paulo e do Rio de Janeiro (RJ) foram palcos privilegiados dessas ações, simultaneamente sociopolíticas, coletivas, anónimas ou estéticas, mas em que a luta social pode equacionar-se com a pulsão desesperada do indivíduo em busca de si próprio.

Em todas as manifestações deste período na cidade de SP, a esmagadora maioria dos participantes indicaram ser trabalhadores. Como se pode observar no Gráfico 3, a composição dos manifestantes do Rio de Janeiro e a do conjunto das oito capitais (cf. supra nota de rodapé 22), revela uma forte presença de jovens trabalhadores ou com algum contacto com o mercado trabalho (70,4\% na primeira amostra e $76 \%$ na segunda), sendo que aqueles inseridos em famílias que auferem até 2 salários mínimos (SM) correspondem 
a $34,3 \%$ no RJ e a $15 \%$ no conjunto das oito capitais estaduais. Já nos estratos de rendimento familiar acima disso, as famílias que se situam entre 2 e 5 SM têm um peso de $30 \%$ na amostra do IBOPE (oito capitais) e de $54,1 \%$ nos manifestantes do RJ do dia 20 de junho. Em suma, cerca de metade dos manifestantes inseriam-se em famílias cujo rendimento médio é inferior a 5 SM (cerca de 3800,00 R \$, ou seja, 1225,00 euros), mas uma parte significativa destes ( $35 \%$ na manifestação do RJ no dia 20 de junho) pertenciam a famílias de rendimento até $2 \mathrm{SM}$.
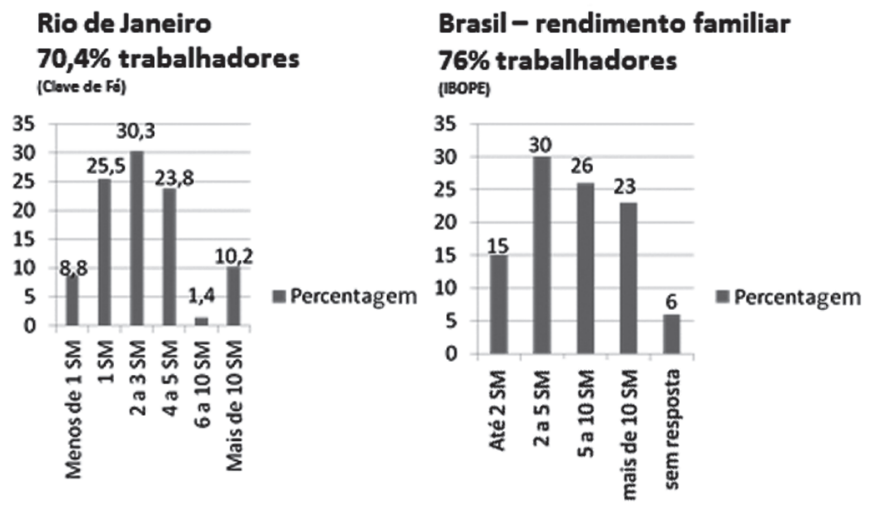

GRÁFICO 3 - Manifestantes, 20 de junho de 2013 - Rendimentos

Fonte: IBOPE/ Clave de Fá, 23/06/2013 (cf. supra nota de rodapé 22).

Porém, no conjunto dos manifestantes das referidas oito cidades, cerca de $23 \%$ da amostra das oito capitais era oriunda de famílias com níveis salariais acima dos 10 SM (6800,00 R\$, ou seja, 2193,00 euros), embora na manifestação do RJ esse valor fosse apenas de 10,2\% (segundo a sondagem da Clave de Fá). Não sendo evidente uma condição social sustentada de classe média, parece, todavia, claro que se trata de franjas sociais que se demarcam dos grupos de referência que deixaram para trás, ou seja, as gerações proletarizadas de onde a maior parte é oriunda. $\mathrm{E}$ ao mesmo tempo, a maioria esmagadora dos manifestantes não era filiada em partidos políticos $(96 \%)$ nem em sindicatos (86\%) (a comprovar que também não pertenciam ao operariado industrial). ${ }^{23}$

${ }_{23}$ De resto, como se sabe, as estruturas sindicais brasileiras foram surpreendidas com estas manifestações e, grosso modo, acusaram-nas de serem manobradas pela direita e pelos média. 
Como se sabe, o impacto das manifestações foi enorme no Brasil e fora dele. A Presidente Dilma Rousseff reconheceu, em declaração solene transmitida nas televisões, que as manifestações "mostraram a força da nossa democracia e o desejo da juventude fazer o Brasil avançar. Se aproveitarmos bem o impulso dessa nova energia política poderemos fazer melhor e mais rápido muita coisa que o Brasil ainda não conseguiu realizar [...]" (Pronunciamento da Presidente Dilma Rousseff no dia 21.06.2013 - TV Globo). Mas isso não evitou (pelo menos no imediato) a quebra abrupta de confiança por parte do eleitorado nas instituições e atores sociais do Brasil, o que pode ser conferido comparando os resultados de 2012 com os de julho de 2013, após o fecho deste ciclo de rebeliões. De acordo com estudos de opinião do IBOPE, a queda dos níveis de aprovação incidiu sobretudo nos seguintes itens: Presidência da República - de $63 \%$ para $42 \%$ de aprovação; sistema público de saúde - de $42 \%$ para $32 \%$; Governo Federal - 53\% para 41\%; Congresso Nacional - 36\% para $29 \%$; sindicatos $-44 \%$ para $37 \%$ (IBOPE, 31.07.2013).

\section{Conclusão}

O ciclo de manifestações que atingiu o mundo nos últimos três anos evidenciou uma variedade de fatores, de contextos políticos e socioculturais, de níveis de consciência social e de experiências de ativismo, de tal modo vasta que se torna difícil encontrar elementos de comparação entre fenómenos tão dispersos. No entanto, o mundo interconectado em que vivemos estabelece ligações improváveis que transcendem a geografia, circulando e metamorfoseando-se através de novos canais de ligação entre o real e o virtual, cujo efeito prático pode ser a alteração das estruturas simbólicas de significado e as lógicas de ação de grupos particulares.

A juventude e a precariedade foram elementos centrais nesta reflexão, tanto nas lutas dos precários em Portugal e no Sul da Europa, como nas sublevações de junho de 2013 no Brasil, embora neste caso houvesse poucas referências expressas à questão laboral. Uma juventude escolarizada, muito familiarizada com as novas redes sociais de comunicação e cujas trajetórias se dirigem à classe média ou sofrem a influência dos seus padrões de vida e de consumo. Se, por um lado, os recursos educacionais, a estabilidade no emprego e o acesso ao crédito permitiram uma aproximação aos degraus intermédios da escada social, por outro, os recursos económicos e as condições de vida sofreram os efeitos das medidas de austeridade (sobretudo no caso português) ou os custos de uma degradação das condições sociais, das políticas públicas e das infraestruturas que inviabilizaram a consolidação de direitos e oportunidades fundamentais (sobretudo no caso brasileiro). 
Os momentos de maior radicalismo destas mobilizações evidenciaram a força política e simbólica das lutas coletivas e dos momentos de indignação, mas ao mesmo tempo expuseram uma lógica individual cujos sinais se tornaram visíveis no próprio seio da multidão durante os protestos. Essa ambivalência entre o indivíduo e o grupo foi detetada nas maiores manifestações em Portugal (e por exemplo nos Indignados em Espanha), visto que o discurso e as atitudes coletivistas e solidaristas surgiram lado a lado com os slogans mais individualistas ("eu quero ser feliz") e as exigências de mais democracia surgiram lado a lado com a linguagem "antipolítica" e de repúdio aos valores e aos agentes institucionais da democracia ("o povo unido não precisa de partido!”).

Dir-se-á que os sentidos contraditórios destes processos se exprimem ao mesmo tempo numa dinâmica de rebeldia, fazendo jus à indignação de uma classe trabalhadora precarizada, mas paradoxalmente também na performance individual e nos sinais latentes de consumismo, que veiculam um ethos de classe média. Tais tendências ambivalentes são reveladores da complexidade, mas também, em especial no Brasil, da crescente consciência social com que se debatem os que exigem ver reconhecidos os direitos, as oportunidades e a dignidade que nunca tiveram, enquanto outros, em especial em Portugal, exprimem a frustração e o desespero de quem já teve direitos consagrados e se confronta hoje com a sua revogação brusca, por imposição do poder económico e de um poder político desacreditado.

Ao assinalar a pulsão de classe média, que, aparentemente, marcou este ciclo de protestos, não pretendi diminuir o potencial político e mesmo emancipatório destas lutas, até porque as intensas convulsões sociais e o radicalismo que algumas delas evidenciaram não deixam de constituir ingredientes constitutivos de novas identidades, onde se forjam muitas vivências emocionais e de elevado risco, que podem reforçar as culturas de resistência, experiências de solidariedade e a capacidade de rutura perante instituições e poderes até então considerados insuperáveis. Quer na Europa do Sul quer no Brasil, a classe trabalhadora tem sofrido uma rápida recomposição e segmentação. Por isso mesmo, quando aqui enfatizei a noção de "classe média", pretendi, mais do que invocar um ator substantivo, sugerir um modo diferente de pensar as transformações em curso no mundo do trabalho e da ação coletiva.

A classe trabalhadora brasileira - em especial os seus segmentos jovens e escolarizados - é herdeira de uma condição miserável que até recentemente a amarrou a dependências e preconceitos cuja génese remete para os tempos da escravatura e do colonialismo. Só na última década ocorreu um vislumbre de emancipação com progressos assinaláveis no plano do reconhecimento 
de direitos e no acesso a benefícios sociais, mas isso foi acompanhado da emergência de novos segmentos inseguros e precários, apesar de mais instruídos. Estas novas camadas sociolaborais, não sendo parte de uma classe média de facto, inserem-se numa trajetória em redefinição sob o efeito de um status "truncado" (dada a flagrante assimetria entre recursos educacionais e condição económica) e marcados pela insegurança. Trata-se, portanto, de um segmento que se destaca da camada mais acomodada da classe média "tradicional" e é mais propenso à radicalização, mas ao mesmo tempo - essa é a minha convicção - não constitui nem uma vanguarda nem uma nova voz do operariado ou das classes subalternas no seu conjunto.

No contexto europeu e em Portugal o "efeito classe média" ocorreu sob uma dupla lógica: primeiro, porque a indignação foi em larga medida consequência da contração do Estado social que tinha sido o principal "ascensor" da classe média assalariada; segundo, porque também na Europa do Sul as dinâmicas de juventude presentes nas manifestações "inorgânicas" e nas "acampadas" exprimiram a indignação e rebeldia dos segmentos mais instruídos, qualificados e familiarizados com as novas redes e plataformas de ativismo informático. Ficou claro o desejo generalizado de defesa da coesão e da justiça social, mas, ao mesmo tempo, um sentimento latente de insatisfação individual e de realização do sonho consumista por cumprir, ou que foi inesperadamente defraudado.

Se a estabilidade e a previsibilidade do quotidiano são traços marcantes do habitus de "classe média", a condição precária é exatamente a negação disso. Pode dizer-se que no caso brasileiro a "classe média" 24 é um constructo (talvez mesmo uma miragem), enquanto no caso português é uma descida ao purgatório de quem julgava estar às portas do paraíso. Ora, dependerá do grau de rigidez dos atuais bloqueios do Estado social, das instituições democráticas e do capitalismo global, da sua força e capacidade de reinvenção, se estes fenómenos virão a intensificar-se ou a esbater-se no futuro. Não se espera, naturalmente, que destes movimentos renasça um novo hipersujeito que protagonize a revolução "redentora" do século XXI. Mas a recomposição em curso da classe trabalhadora e do precariado, associada à reconfiguração dos antagonismos estruturais da economia e ao papel dos novos meios e redes de comunicação, deixam em aberto um imenso potencial para os novos palcos e modalidades de ativismo. As rebeliões de massas adquirem nos dias de hoje novos

\footnotetext{
${ }^{24}$ Aqui entendida como os novos segmentos emergentes de assalariados jovens e com elevado capital educacional, e, no caso de Portugal, como sinónimo dos setores estáveis do antigo emprego "seguro" e do funcionalismo.
} 
contornos, mas a velha tensão entre o consentimento alienante e a politização da sociedade está longe de chegar ao fim.

Recebido a 08.02.2014

Aprovado para publicação a 30.04.2014

\section{Referências bibliográficas}

Adamovski, Ezequiel (2013), “'Clase media': reflexiones sobre los (malos) usos académicos de una categoria”, Nueva Sociedad, 247, 38-49.

Antunes, Ricardo (2013), Os sentidos do trabalho. Coimbra: Almedina.

Arcary, Valério (2013), "Até onde vamos aguentar?”. Entrevista publicada no Blogue de Leituras -Raquel Varela, em 30 de outubro de 2013. Consultado a 24.03.2013, em http:// raquelcardeiravarela.wordpress.com/2013/10/30/ate-onde-vamos-aguentar/.

Barker, Colin (2008), "Some Reflections on Student Movements of the 1960s and Early 1970s”, Revista Crítica de Ciências Sociais, 81, 43-91.

Bartelt, Dawid Danilo (org.) (2013), A 'nova classe média' no Brasil como conceito e projeto politico. Rio de Janeiro: Fundação Heinrich Böll Stiftung.

Boltanski, Luc; Chiapello, Ève (2001), Le nouvelle esprit du capitalisme. Paris: Gallimard.

Bourdieu, Pierre (1979), La distinction. Critique sociale du jugement. Paris: Seuil.

Burawoy, Michael (2009), O marxismo encontra Bourdieu. Campinas: Editora da Unicamp.

Braga, Ruy (2012), A política do precariado: do populismo à hegemonia lulista. São Paulo: Boitempo.

Cantante, Frederico (2013), "A magreza das classes médias em Portugal", in Renato Miguel do Carmo (org.), Portugal uma sociedade de classes: polarização social e vulnerabilidade. Lisboa: Edições 70/Le Monde Diplomatique, 129-150.

Carmo, Renato Miguel (org.) (2013), Portugal uma sociedade de classes: polarização e vulnerabilidade. Lisboa: Edições 70/Le Monde Diplomatique.

Cohen, Jean L.; Arato, Andrew (1994), Civil Society and Political Theory. Cambridge: MIT Press.

Dallinger, Ursula (2011), "The Endangered Middle Class? A Comparative Analysis of the Role Public Redistribution Plays”, Luxembourg Income Study - Working Paper Series, n. $^{\circ}$ 565. Consultado a 20.12.2013 em http://www.lisdatacenter.org/wps/ liswps $/ 565$.pdf.

Eagleton, Terry (2011), Depois da teoria. Um olhar sobre os estudos culturais e o pós-modernismo. Rio de Janeiro: Civilização Brasileira.

Eder, Klaus (2001), "A classe social tem importância no estudo dos movimentos sociais?”, Revista Brasileira de Ciências Sociais, 16(46), 5-27. 
Engels, Friedrich (2008), A situação da classe trabalhadora na Inglaterra. São Paulo: Boitempo [ed. orig.: 1842].

Erikson, Robert; Goldthorpe, John (1992), Constant Flux: A Study of Class Mobility in Industrial Cocieties. Oxford: Clarendon Press.

Esping-Andersen, Gøsta (org.) (1996), Welfare States in Transition. National Adaptations in Global Economies. London: Sage.

Estanque, Elísio (2003), "O efeito classe média - Desigualdades e oportunidades no limiar do século XXI”, in Manuel Villaverde Cabral; Jorge Vala; André Freire (orgs.), Percepções e avaliações das desigualdades e da justiça em Portugal numa perspectiva comparada. Lisboa: ICS, 69-105.

Estanque, Elísio (2012), A classe média. Ascensão e declínio. Lisboa: Fundação Francisco Manuel dos Santos/Relógio d'Água.

Estanque, Elísio; Bebiano, Rui (2007), Do activismo à indiferença-Movimentos estudantis em Coimbra. Lisboa: ICS.

Estanque, Elísio; Costa, Hermes Augusto (2011), O sindicalismo português e a nova questão social - Crise, consolidação ou renovação? Coimbra: CES/Almedina.

Estanque, Elísio; Costa, Hermes Augusto; Soeiro, José (2013), “The New Global Cycle of Protest and the Portuguese Case", Journal of Social Science Education, 12(1), 31-40.

Estanque, Elísio; Mendes, José Manuel (1997), Classes e desigualdades sociais em Portugal - um estudo comparativo. Porto: Afrontamento.

Ferreira, António Casimiro (2012), Sociedade da austeridade e direito do trabalbo de exceção. Porto: Vida Económica.

Guimarães, António Sérgio (2002), Classes, raças e democracia. São Paulo: Editora 34.

Harvey, David et al. (2012), Occupy. Movimentos de protesto que tomaram as ruas. São Paulo: Boitempo/ Carta Maior.

Huws, Ursula (2003), The Making of a Cybertariat: Virtual Work in a Real World. New York: Monthly Review Press.

Krein, José Dari; Baltar, Paulo Eduardo (2013), "A retomada do desenvolvimento e a regulação do mercado do trabalho no Brasil”, Cadernos CRH, 26(68), 273-292.

Laclau, Ernesto (1996), Emancipation(s). London: Verso.

Lenine, V. I. (1977), Obras Escolbidas, vol. I., t. 1. Lisboa-Moscovo: Edições Progresso.

Marx, Karl (2008), O Capital - Crítica da Economia Política, Livro 3. Vol. 6. Rio de Janeiro: Civilização Brasileira.

Melucci, Alberto (2001), A invenção do presente. Rio de Janeiro: Vozes.

Neri, Marcelo (2012), A nova classe média: o lado brilhante da base da pirâmide. São Paulo: Fundação Getúlio Vargas/Editora Saraiva.

Nobre, Marcos (2013a), Choque de democracia - Razões da revolta. São Paulo: Companhia das Letras. 
Nobre, Marcos (2013b), Entrevista ao Jornal da Unicamp, 28 de julho de 2013. Consultado a 19.12.2013, em http://www.unicamp.br/unicamp/ju/567/revoltas-decretam-o-fim-do-ciclo-de-redemocratizacao-diz-docente.

Nunes, Nuno (2013), Desigualdades sociais e práticas de ação coletiva na Europa. Lisboa: Editora Mundos Sociais.

Pais, José Machado (1990), “A construção sociológica da juventude”, Análise Social, 105/106, 139-165.

Parkin, Frank (1968), Middle Class Radicalism. Manchester: Manchester University Press.

Parkin, Frank (1979), Marxism and Class Theory: A Bourgeois Critique. London: Tavistock.

Pochmann, Márcio (2012), Nova classe média? O trabalho na base da pirâmide social. São Paulo: Boitempo.

Pinto, António Costa; Sousa, Luís de; Magalhães, Pedro (orgs.) (2013), A qualidade da democracia em Portugal. Lisboa: Editora do ICS.

Santos, Boaventura de Sousa (2003) (org.), Democratizar a democracia: os caminhos da democracia participativa. Porto: Afrontamento.

Santos, Figueiredo José Alcides (2004), Estrutura de posições de classe no Brasil: Mapeamento, mudanças e efeitos na renda. Belo Horizonte: Editora da UFMG.

Savage, Mike et al. (2013), "A New Model of Social Class? Findings from the BBC's Great British Class Survey Experiment”, Sociology 0(0), abril, 1-32.

Soeiro, José (2014), "Da Geração à Rasca ao Que se Lixe a Troika. Portugal no novo ciclo internacional de protesto", Sociologia: Revista do Departamento de Sociologia da FLUP, XXVIII, disponível em http://ler.letras.up.pt/site/default. aspx?qry=id04id $111 \&$ sum $=$ sim.

Souza, Jessé de (2010), Os batalhadores brasileiros: nova classe média ou nova classe trabalhadora? Belo Horizonte: Editora da UFMG.

Standing, Guy (2009), Work after Globalisation: Building Occupational Citizenship. Cheltenham: Elgar.

Standing, Guy (2013), O precariado. A nova classe perigosa. São Paulo: Editora Autêntica.

Standing, Guy (2014), "O precariado e a luta de classes", Revista Crítica de Ciências Sociais (neste volume).

Taylor, Astra et al. (orgs.) (2011), Occupy. Scenes from Occupied America. London: Verso.

Touraine, Alain (1985), "An Introduction to the Study of Social Movements", Social Research, 52(4), 749-788.

Touraine, Alain (2006), "Na fronteira dos movimentos sociais", Sociedade e Estado, 21(1), 17-28.

Thompson, E. P. (1982), A formação da classe operária inglesa. Rio de Janeiro: Paz e Terra [ed. orig.: 1963]. 
80| Elísio Estanque

Velasco, Pilar (2011), NO Nos Representan. El Manifesto de Los Indignados en 25 Propuestas. Madrid: Ediciones Planeta Madrid S.A.

Žižek, Slavoj (2013), "Problemas no paraíso”, in Slavoj Žižek et al., Cidades Rebeldes: passe livre e as manifestações que tomaram as ruas do Brasil. São Paulo: Boitempo/ /Carta Maior, 101-108. 